\title{
Multiple Pterygium Syndrome
}

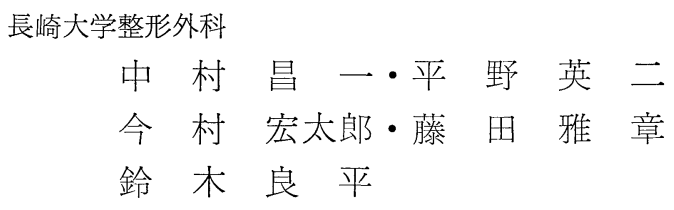

国立小浜病院整形外科

久芳 昭 紘

\section{A Case of the Multiple Pterygium Syndrome}

by

\author{
M. Nakamura, E. Hirano, K. Imamura, M. Fujita, \\ R. Suzuki and A. Kuba \\ Department of Orthopaedic Surgery, Faculty of \\ Medicine, Nagasaki University
}

\begin{abstract}
The multiple pterygium syndrome is a rare condition which consists of pterygia of neck, antecubital, digital, popliteal, and intercrural areas, growth reteardation, peculiar facies, foot deformities, multiple joint contractures, vertebral anomalies. Here we report a girl with multiple pterygium syndrome. This case is a sporadic type because of mild symptom and no evidence in her family history. We believe this is the first reported case of the multiple pterygium syndrome in Japan.
\end{abstract}

\section{は じめに}

翼状変形をきたす疾患としては, 翼状頸を特徴とす る Turner 症候群がよく知られているが，全身的な 翼状変形を特徵とする疾患に, Multiple Pterygium Syndrome（以下 MPS）と略す）がある.MPS は, 多発する翼状変形の他飞, 成長遅延・特異な顔貌・足 部変形・脊椎変形等を示す非常に稀な疾患であり, 我 我が渉猟しえた限りに扔いては，本邦における報告例 はない，今回我々は，MPS と思われる症例を経験し たので, 若干の文献的考察を加えて報告する.

\section{症例}

患者：17才，女子高校生

主訴：右手指屈拘縮及び両足変形

既往歷及び家族歴：特記事項なし. 同様の所見を呈 した者はいなかった。

現病歴：生後すぐに右手指の屈曲拘縮及び両内反足 に気づく. 両者共, 加令とともに增悪. S 52 年 3 月,
全身倦怠・発熱のため当院小児科に入院. このとき， 小頭症・翼状頸・眼球突出・球瞼下垂・両内反足・右 手指屈曲拘縮 (屈指症) 等の多発奇形を指摘され, 染 色体異常又はアミノ酸代謝異常の疑いにて精査うける あ異常なし．その後は放置していた．S57 年 12 月， 右屈指症・両内反足に対する手術目的にて当科入院之 なる。

理学的所見：身長 $144 \mathrm{~cm}$, 体重 $34 \mathrm{~kg}$. 翼状変形 は，頸部・腋窩部・指節間関節部・膝窩部にみられ た. 顔貌は, 眼瞼下垂・眼球突出・眼間難開・低耳介 -長く狭い鼻・ 口角下垂・歯牙欠損・小サく後方へ落 ちこんだ下顎 (小頭症) 等で, いわゆる鳥顔貌を呈し ていた，両肩関節・右手指関節（屈指症）・両足関節 （内反足）に拘縮がみられ，脊椎は右凸の軽度側彎を 呈していた，成長遅延むみられた．性器奇形はなかっ た (図 $1 \sim 4$ ).

検查所見: 血液・生化学, 尿検査と屯に正常. 内分 泌機能も異常なく, 染色体検査も，46XX と正常女 性型を示した. 神経伝導速度も正常. 血中アミノ酸分 
析で, システィンの低下とリジンの軽度増加がみられ た.

手術所見：右手届指症は, 第 2 - 3 -4 指に届曲拘 縮があったが，いずれも浅指屈筇腱の異常はなく，第 3 - 4 指は Z-plasty による皮膚の延長のみで拘縮が 除去され，第 2 指は PIP 関節の側副靱帯の切離によ ってはじめて可動性を獲得できた.

右内反足については，Lambrinudi の距骨下三関節 固定のみでは矯正できず, 足底解離・アキレス腱延長 術を付加した。

\section{考察}

過去の報告例を調べてみると, 1902 年に Bassiere が不全型と思われる症例を初めて報告. 1936 年に Matolcsy が，特異な顔貌・多発する翼状変形・指の 変形・足部変形・関節拘縮を有する，ほぼ完全型と思

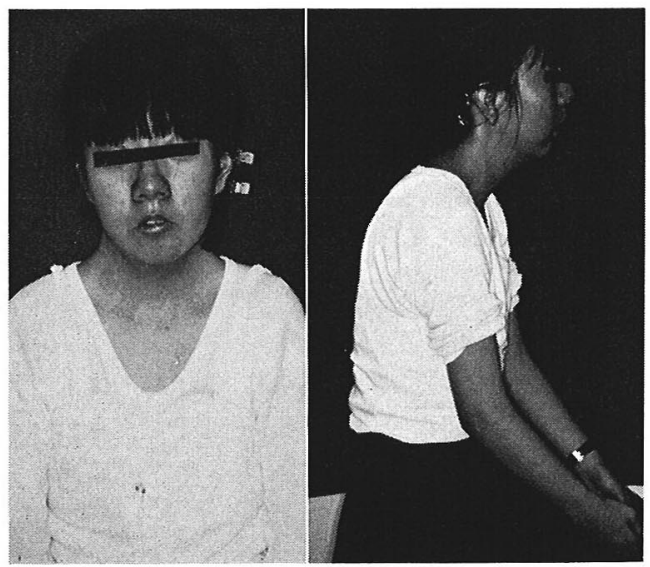

図1 特異な顔貌.〈わしい所見は本文参照.

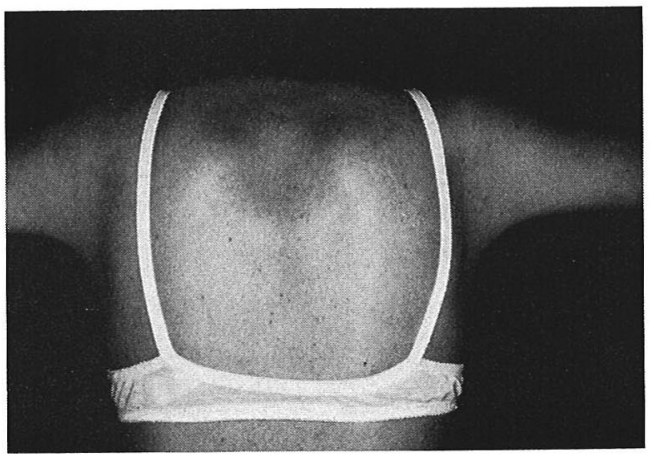

図 2 腋品部の翼状変形。両肩最大外転位
われる症例を報否. 以後, 1947 年に Guinand-Doniol, 1960 年に Lang, 1968 年に Srivastava, 1969 年に Norum, Scott, 1971 年に Aarskog, 1973 年 に Carnevail et al. らの報告がある. 1978 年に Temtamy と Mckusick によって，翼状変形をきた す疾患群の体系が確立された。 即ち，(1) Syndrome with Pterygium Colli, (2) The Popliteal Pterygium Syndrome, (3) The Antecubital Pterygium Syndrome, (4) Generalized Pterygium Syndrome の 4 つに分類し，MPS は（4）に属する. 最近では, 1980 年に Harold Chen et al. が, 過去 の報告例も含めて 23 例をまとめて報告している.

遺伝性に関しては，次の 4 つが報告されている.

（1）常染色体劣性，（2）常染色体優性，（3）散発性,

（4）染色体異常. このうち，（1）が最も多く，(2),

（3）が散見される程度で，(4) は1例報告されている のみである，症状は，(1) と（3）が似ており，(3) が より程度が軽い。また，(2) と（4）では, 性器異常

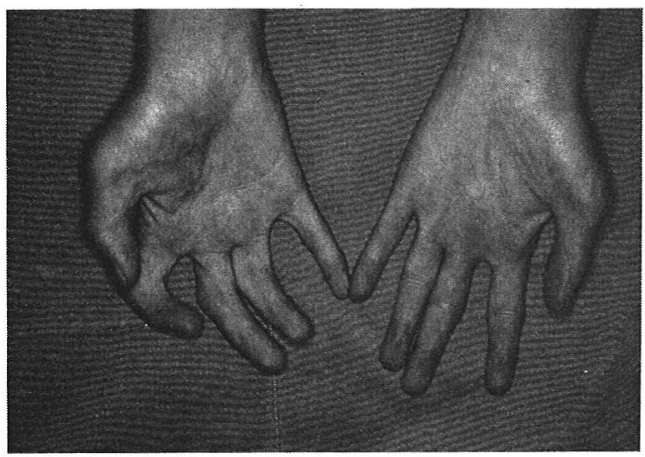

図3右屈指症

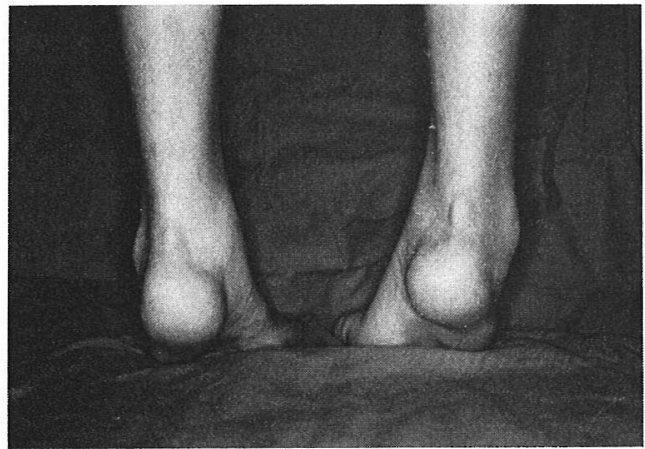

図4 足部裂形。両側共に内反尖足位にある。 
表 1 常染色体劣性, 優性及び我々の症例に括け る症状の比較

\begin{tabular}{l|c|c|c}
\hline \hline \multirow{2}{*}{ Manlfestation } & $\begin{array}{c}\text { Present } \\
\text { case }\end{array}$ & $\begin{array}{c}\text { Multlple } \\
\text { pteryglum } \\
\text { syn. }\end{array}$ \\
\cline { 3 - 4 } & & $\begin{array}{c}\text { A. R. } \\
(\%)\end{array}$ & A. D. \\
\hline Cutaneous and musculos & & & \\
\hline Pteryglum & & & \\
Neck & & $O(100)$ & $\bigcirc$ \\
Axlllary & $\bigcirc$ & $\bigcirc(61)$ & $\times$ \\
Antecubltal & $\times$ & $\bigcirc(91)$ & $\bigcirc$ \\
Popllteal & $\bigcirc$ & $\bigcirc(91)$ & $\bigcirc$ \\
Intercrural & $\times$ & $\bigcirc(65)$ & $\times$ \\
Dlgltal & $\bigcirc$ & $\bigcirc(78)$ & $\triangle$ \\
Multiple contracture & $\bigcirc$ & $\bigcirc(83)$ & $\bigcirc$ \\
Vertebral anomalles & $\bigcirc$ & $\bigcirc(48)$ & $\bigcirc$ \\
Foot anomalles & $\bigcirc$ & $\bigcirc(61)$ & $\times$ \\
Growth retardation & $\bigcirc$ & $\bigcirc(100)$ & $\times$ \\
Genital anomalles & $\times$ & $\bigcirc(60)$ & $\times$ \\
Orofaclal anomalles & $\bigcirc$ & $\bigcirc(54)$ & $\bigcirc$ \\
& &
\end{tabular}

A. D.: Autosomal Dominant.

A. R.: Autosomal recessive. 右の 2 つは文献より引用.（）内は発現頻度を示 す.

や知能障害等の多少異なった症状が発現している. 我 々の症例では，正常の染色体像を示していた.

Etiology は，現在のところ不明である. Lang (1960) によれば, 筋生検によって, 筋の変性や筋繊維 の分裂などの廃用性萎縮に適合する所見がみられ, 免 疫学的にも, Immunoglobrin • Complement • Fibrinogen が筋繊維や血管壁に存在するという報告 が あるが，まだ本態を解明するとてろまでは至っていな い.アミノ酸代謝の異常を指摘した報告ああり, 我々 の症例においても，血中アミノ酸值の異常がみられ た. リジン代謝異常症と低身長についての報告あある が，他の合併奇形との関連については述べられておら ず, 我々の症例でも確定晾断に必要な酵素活性の測定 を行なっていないため, 今後更に研究を進めていく必 要がある.

Halold Chen らによって示された Criteria を大 まかに示すと，（1）多発する翼状変形，（2）関節拘 縮,（3）特異な顔貌，（4）足部変形，（5）成長遅延,

（6）性器異常，（7）骨格の異常である．我々の症例を Criteria に照らしてみると（表一1），ほぼ全てをみ たしている. 文献例は, 過去の報告の集大成であるこ とを考え合わせると，完全型に近い症例ではないかと 思われる.

鑑別診断としては，以下のあのがあげられる.
Arthrogryposis Multiplex Congenita, (2) Popliteal Pterygium Syndrome, (3) Freeman-Sheldon Syndrom, (4) Gordon Syndrome, (5) Noonan Syndrome, (6) Turner Syndrome, (7) Klippel-Feil Syndrome 等である. このうち, (1), (3)，（4)，(7）は，翼状変形を示さず，（2）は MPS の一部分症とも考えられ, 膝窩部に限局している点で 鑑別される.（5）については，症状は似通っている が, 先天性心奇形に伴う全身奇形という点で異なり, （6）は XO 型の染色体をもち, 知能障害や外反肘, X線的に骨萎縮を伴う点からも, 容易に鑑別されるで あろう.ただ，過去に扑いて，てれらの病名で報告さ れた MPS の症例むかなり多いのではないかと推察さ れる.

\section{ま と め}

我々が渉猟しえた限りに执いて，本邦において報告 例のない非常に稀な MPS と思われる1例につき報告 した．症状は揃っているが程度が軽いことや，家族歴

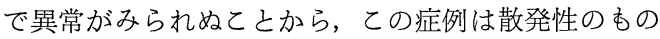
であろうと推測される.

\section{参 考 文 献}

1) Carnevale A, Hernandez AL, Cobos LDL $\mathrm{V}$ : Sindrome de pterygium familiar con probable transmission dominante ligada al chromosoma X. Rev Invest Clin 25: 237244, 1973.

2) Chen H., Chang C. H., Misra R., Peters, A. H., Grijalva N. S. and Opitz M. J.: Multiple ptergium syndrome. Am. J. Med. Genetics 7: 91-102, 1980.

3) Escobar V, Bixler D, Gleiser S, Weaver DD, Gibbs T: Multiple pterygium syndrome. Am. J. Dis. Child. 132: 609-611, 1978.

4) Escobar V, Weaver D.: Popliteal pterygium syndrome. A phenotypic and genetic analysis. J. Med. Genet. 15: 35-42, 1978.

5) Gillin ME, Pryse-Davis J: Pterygium syndrome. J. Med. Genet. 13: 249-251, 1976.

6) Lang V. K, Lelback W. K, Lolmant. J.: Betrag zum Bilde der Pterygomyodisplasid artrogrypotica generalis. Monatsschr Kinderheilked 108: 248-252, 1960.

7) Pashayan H, Dallaire L, Macleod P. : Bilateral aniridia, multiple webs and severe mental retardation in a $47, \mathrm{XXY} / 48, \mathrm{XXXY}$ mosaic. Clin. Genet. 4: 125-129, 1973. 
質 問

翼状変形は，スライドではよくわからなかったが，

一見してわかるあのなのか.
解 答

長崎大学 中村 昌一

我々もこの症例 1 のみで断言はできないが，乙の症 例に関していえば, neck, axillary の翼状変形は, 一見してそれとわかるあのであった. 